Pediatr Clin North Am. 2013 February ; 60(1): 189-207. doi:10.1016/j.pcl.2012.09.008.

\title{
Human milk for the premature infant
}

\author{
Mark A. Underwood ${ }^{\mathrm{a}}$ \\ aAssociate Professor, Department of Pediatrics, University of California, Davis, California, USA
}

\section{Synopsis}

Premature infants are a heterogeneous group with widely differing needs for nutrition and immune protection with risk of growth failure, developmental delays, necrotizing enterocolitis, and lateonset sepsis increasing with decreasing gestational age and birth weight. Human milk from women delivering prematurely has more protein and higher levels of many bioactive molecules compared to milk from women delivering at term. Human milk must be fortified for small premature infants to achieve adequate growth. Mother's own milk improves growth and neurodevelopment and decreases the risk of necrotizing enterocolitis and late-onset sepsis and should therefore be the primary enteral diet of premature infants. Donor milk is a valuable resource for premature infants whose mothers are unable to provide an adequate supply of milk, but presents significant challenges including the need for pasteurization, nutritional and biochemical deficiencies and a limited supply.

\section{Keywords}

human milk; premature infant; necrotizing enterocolitis; donor milk; lactation

\section{Introduction}

Human milk provides the optimal nutrition for term infants. Human milk is also recommended for preterm infants, but does not alone provide optimal nutrition. The growth and neurodevelopmental needs of the evolutionarily new population of very premature infants are best met by appropriate fortification of human milk. To explore the role of human milk in the care of premature infants, it is appropriate to begin with a comparison of amniotic fluid (the optimal beverage of the fetus), milk from mothers delivering preterm, and milk from mothers delivering at term. We will then consider the benefits and challenges of providing human milk to premature infants, approaches to human milk fortification, the advantages and challenges of donor human milk products, and finally some practical approaches to increasing human milk consumption in premature infants.

In the United States, approximately $12 \%$ of infants are born preterm (prior to 37 weeks gestation). ${ }^{1}$ This is a very heterogeneous population with widely diverse nutritional requirements and highly different stages of immunocompetence. A $2.5 \mathrm{~kg}$ neonate born at 34

\footnotetext{
(c) 2012 Elsevier Inc. All rights reserved.

Corresponding author: Mark A. Underwood MD, MAS, Department of Pediatrics, 2516, Stockton Blvd, Sacramento CA 95817, USA. Phone 916-734-5779, FAX 916-703-5061, munderwood@ucdavis.edu.

Publisher's Disclaimer: This is a PDF file of an unedited manuscript that has been accepted for publication. As a service to our customers we are providing this early version of the manuscript. The manuscript will undergo copyediting, typesetting, and review of the resulting proof before it is published in its final citable form. Please note that during the production process errors may be discovered which could affect the content, and all legal disclaimers that apply to the journal pertain.

Conflict of interest: none
} 
weeks gestation differs from a 500 gram neonate born at 24 weeks gestation in essentially every physiologic aspect of the gastrointestinal system and the innate and adaptive immune systems. Consequently the current body of knowledge about nutrition and host defense of premature infants has many gaps. Studies performed on larger older premature infants may not be applicable to the extremely low birth weight infants (ELBW, <1000 grams) that now survive routinely.

\section{Amniotic fluid, "Premature" human milk, and "Term" human milk}

Amniotic fluid contains amino acids, proteins, vitamins, minerals, hormones, and growth factors. While the concentration of these nutrients is much lower than that found in human milk, the large volumes of amniotic fluid swallowed in utero (up to a liter a day late in gestation, considerably more than the newborn consumes after birth) have a significant impact on growth and maturation of both the fetus and the fetal intestine. ${ }^{2}$ Animal studies and limited human observations suggest that swallowed amniotic fluid accounts for about $15 \%$ of fetal growth. ${ }^{3-5}$

Milk from women who deliver prematurely differs from that of women who deliver at term. Preterm milk is initially higher in protein, fat, free amino acids, and sodium, but over the first few weeks following delivery these levels decrease (Figure 1A). The mineral content (including trace minerals) of preterm milk is similar to that of term milk, with the following exceptions: calcium is significantly lower in preterm milk than term milk and does not appear to increase over time while copper and zinc content are both higher in preterm milk than term milk and decrease over the time of lactation. ${ }^{6,7}$

Lactose is the major carbohydrate in human milk. This disaccharide is an important energy source, is relatively low in colostrum, and increases over time with more dramatic increases in preterm milk (Figure 1A). Complex oligosaccharides are the second most abundant carbohydrate in human milk. These human milk oligosaccharides (HMOs) are not digestible by host glycosidases and yet are produced in large amounts with highly variable structures by the mother. ${ }^{8}$ HMOs appear to have three important functions: prebiotic (stimulation of commensal bacteria containing the bacterial glycosidases to deconstruct and consume the HMOs), ${ }^{9,} 10$ decoy (structural similarity to the glycans on enterocytes allows HMOs to competitively bind to pathogens), ${ }^{11}$ and provision of fucose and sialic acid that appear to be important in host defense and neurodevelopment respectively. ${ }^{12}$ Preterm milk is highly variable in HMO content. Differences between mothers are due to genetic diversity; ${ }^{13}$ there is also significant variability over time in content of fucosylated HMOs in individual mothers delivering preterm. ${ }^{14}$ Glycosaminoglycans (GAG) also appear to act as decoys providing binding sites for pathogenic bacteria to prevent adherence to the enterocyte. Premature milk is richer in GAG than term milk. ${ }^{15}$

Bioactive molecules in human milk are important components of the innate immune system. Differences in cytokines, growth factors and lactoferrin between preterm and term milk are most dramatic in colostrum and early milk and mostly resolve by 4 weeks after delivery (Figure 1B). Leptin is produced by mammary glands, secreted into human milk, and may be important in post-natal growth. Human milk leptin does not appear to differ between preterm and term milk. ${ }^{16}$ Bile salt-stimulated lipase activity is similar in term and preterm milk while lipoprotein lipase activity is higher in term milk. ${ }^{17}$

\section{Benefits of human milk for premature infants}

The most recent policy statement from the Section on Breastfeeding of the American Academy of Pediatrics represents a significant shift from previous statements in its recommendation that all preterm infants should receive human milk, with pasteurized donor 
milk rather than premature infant formula the preferred alternative if a mother is unable to provide an adequate volume. ${ }^{18}$ The current recommendation is based on an impressive array of benefits that human milk provides to this highly vulnerable population, including decreased rates of late-onset sepsis, ${ }^{19}$ necrotizing enterocolitis (NEC), ${ }^{20,} 21$ and retinopathy of prematurity, ${ }^{22,23}$ fewer re-hospitalizations in the first year of life, ${ }^{24}$ and improved neurodevelopmental outcomes. ${ }^{24-26}$ In addition, premature infants that receive human milk have lower rates of metabolic syndrome, lower blood pressure 27 and low-density lipoprotein levels, ${ }^{28}$ and less insulin and leptin resistance ${ }^{29}$ when they reach adolescence, compared to premature infants receiving formula.

Among these benefits, perhaps the most compelling benefit of human milk feeding is the observed decrease in NEC, given its high prevalence (5-10\% of all infants with birth weight $<1500$ grams), high case fatality, and long-term morbidity due to complications like strictures, cholestasis, short-bowel syndrome, and poor growth and neurodevelopment. ${ }^{30}$ For many of these outcomes there appears to be a dose response effect of human milk feeding. For instance, a dose of mother's own milk $>50 \mathrm{ml} / \mathrm{kg} / \mathrm{d}$ decreases the risk of late-onset sepsis and NEC compared to $<50 \mathrm{ml} / \mathrm{kg} / \mathrm{d}^{21,31}$ and for each $10 \mathrm{ml} / \mathrm{kg} / \mathrm{d}$ increase in human milk in the diet there is a $5 \%$ reduction in hospital readmission rate. ${ }^{26}$ The mechanisms by which human milk protects the premature infant against NEC are likely multifactorial. Human milk sIgA, lactoferrin, lysozyme, bile salt-stimulating lipase, growth factors, and HMOs all provide protective benefits that could potentially contribute to reduction in NEC. In a multi-center randomized clinical trial, bovine lactoferrin treatment decreased late-onset sepsis but not NEC in premature infants. ${ }^{32}$ Recombinant human lactoferrin trials are currently in progress in premature infants (clinicaltrials.gov NCT00854633). In animal models, epidermal growth factor (EGF) ${ }^{33}$ and pooled HMOs ${ }^{34}$ prevent NEC, but these have not yet been tested in premature infants.

Microbial colonization is thought to play an important role in risk of NEC. ${ }^{35,36}$ Breast feeding is one of many factors that influence the composition of the intestinal microbiota in term infants; ${ }^{37}$ limited studies suggest that diet may have less of an effect on the composition of the intestinal microbiota in the premature infant than other factors (such as antibiotic administration). ${ }^{38} \mathrm{New}$ bioinformatic tools to correlate the extensive array of fecal metabolites and the fecal microbiota offer great promise in understanding the factors that influence the microbiota of the premature infant. Studies to date suggest that the metabolites differing between human milk-fed and formula-fed infants that are most closely associated with shaping the microbiota include sugars and fatty acids. ${ }^{39}$ Whether and how these metabolites differ functionally in the extremely premature infant is unknown.

Other potential benefits of human milk to premature infants have been studied with mixed results. There do not appear to be consistent benefits of human milk in premature infants in relation to feeding tolerance, ${ }^{19}$ time to full enteral feeding, ${ }^{24}$ or allergic/atopic outcomes. ${ }^{40}$ Providing human milk has been postulated to decrease parental anxiety, increase skin-toskin contact and parent-infant bonding, but data to support these hypotheses are limited. The provision of human colostrum in the form of oral care for intubated premature infants has been proposed as a method of stimulating the oropharyngeal-associated lymphatic tissue and altering the oral microbiota, but data to support this intervention are lacking. ${ }^{41}$

Studies of the benefits of human milk in premature infants to date have predominantly compared mother's own milk to premature infant formula. Whether pasteurized donor human milk (which generally is provided by women who delivered at term) provides similar or superior protection is unclear. In premature infants receiving only mother's own milk or pasteurized donor human milk (no formula), increasing amounts of mother's own milk correlate with better weight gain and less NEC. ${ }^{42}$ A meta-analysis in 2007 concluded that 
formula feeding was associated with both increased short term growth and increased incidence of NEC compared to donor human milk feeding (RR 2.5 (95\% CI 1.2, 5.1), number needed to harm $33(95 \%$ CI 17, 100)) with no differences in long term growth or neurodevelopment. ${ }^{43}$ However, of the 8 studies included in the meta-analysis, 7 were published before 1990, during which time nutritional comparisons were limited. For example, several of the reviewed studies did not include formulas designed for premature infants and none included nutrient-enriched donor milk. One study, initiated in 1982 followed a cohort of premature infants that received either premature infant formula or unfortified donor human milk with the latter group showing decreased blood pressure 27 and improved lipoprotein profiles as adolescents. ${ }^{28}$ In the single included study published since 1990 , infants whose mothers were unable to provide sufficient milk for their extremely premature infants ( $<30$ weeks gestation) were randomly assigned to receive supplementation with either premature infant formula or nutrient-enriched donor human milk; donor human milk led to slower weight gain but did not decrease episodes of sepsis, or ROP, length of hospital stay or mortality compared to supplementation with premature infant formula. The incidence of NEC was decreased in the donor human milk group by almost half compared to the formula group, but this did not reach statistical significance due to the small sample size. ${ }^{44}$ It is noteworthy in this study that, in spite of increased supplementation in the donor milk group, $20 \%$ of the infants were changed to formula because of poor growth. A more recent comparison of mother's own milk to pasteurized human donor milk demonstrated improved growth and less NEC with the former. ${ }^{42}$

\section{Challenges of providing human milk to premature infants}

Providing human milk to very premature infants presents a variety of challenges. To maximize milk supply, new mothers should begin frequent pumping shortly after delivery. Mothers whose babies are in the NICU should be encouraged to begin pumping within 6-12 hours of delivery and to pump $8-12$ times per day, ensuring that they empty the breast each time. These interventions significantly increase the likelihood that a premature infant will receive his mother's own milk. ${ }^{45}$

Perhaps the biggest concern in providing human milk to premature infants is growth. Term infants undergo rapid growth in the third trimester of pregnancy receiving nutrition through the placenta and swallowed amniotic fluid with no need to expend calories for temperature regulation or gas exchange. Premature infants miss out on much or all of the third trimester and thus have higher nutritional requirements on a per kilogram basis than term infants. Human milk evolved/was designed to nourish the term infant who can tolerate large fluid volumes, whereas premature infants are less tolerant of high fluid volumes.

For these reasons, human milk is generally fortified for premature infants with birth weight less than 1500 grams. Human milk fortifier powders were developed from bovine milk to supplement key nutrients with particular emphasis on protein, calcium, phosphorus, and vitamin D. Fortification of human milk leads to improved growth in weight, ${ }^{46}$ length and head circumference ${ }^{47}$ however improvements in bone mineralization and neurodevelopmental outcomes are unclear. ${ }^{47}$ Recent studies suggest that higher protein intake is beneficial for premature infants. ${ }^{48}$ There is large variation in the energy and protein content of human milk (between mothers, over time in a given mother, and between foremilk and hindmilk). ${ }^{49}$ Protein content decreases over time of lactation and is likely to be much lower in donor human milk than milk from mothers delivering prematurely. Current NICU practices are often based on the clearly misleading assumption that human milk has approximately $0.67 \mathrm{kcal} / \mathrm{ml}$ with stable protein content. "Assumed" protein intake from standard fortification is significantly lower than actual protein intake. ${ }^{50}$ These observations have led to clinical trials of "individualized" fortification, that is, adjusting the amount of 
added protein based on actual measurements of milk samples ${ }^{51}$ or based on metabolic parameters indicative of protein accretion in the neonate (e.g. blood urea nitrogen). ${ }^{52}$ Both methods led to increased protein intake and improved growth. A recent trial of a human milk fortifier with higher protein content demonstrated increased growth and fewer infants with weight below the $10^{\text {th }}$ per centile. ${ }^{53}$

Use of commercial human milk fortifiers, however, is not without complications as demonstrated by the observation of a marked increase in metabolic acidosis associated with the introduction of a new fortifier. ${ }^{54}$ Human milk fortifiers have also been associated with increased markers of oxidative stress compared to unfortified human milk and to infant formula. ${ }^{55}$ In addition, bacterial contamination ${ }^{56}$ of powdered infant formulas and associated sepsis ${ }^{57}$ has been well documented, resulting in more than 100 cases of neonatal Cronobacter (Enterobacter sakazakii) infections leading to high mortality rates. This association has led to calls for "powder-free" NICUs and the development of new liquid human milk fortifiers. Unfortunately, one of the challenges of liquid fortifiers is displacement of the volume of mother's own milk, so that the infant receives less total volume of human milk. Table 1 provides a comparison of the nutrient content and volume of human milk displaced by the liquid formulations of several commercial human milk fortifiers available in North America. Note that the use of the bovine liquid fortifiers means that $17-50 \%$ of the volume ingested is formula. The table also demonstrates the significant variation in macro and micronutrients among these products.

\section{Pasteurized donor human milk for premature infants}

There are significant challenges in providing donor human milk for all premature infants whose mothers are unable to provide an adequate supply of their own milk: nutrition, safety, supply, and immune protection. First, most donor human milk is provided by women who have delivered at term and have weaned their own infant but continue to pump and donate their milk in later lactation. As noted in Figure 1, this milk from mothers of term infants, several months after delivery is low in protein, fat, and many bioactive molecules compared to preterm milk provided in the first few weeks after delivery. A second challenge of providing donor milk is to minimize the potential to transmit infectious agents. For this reason, milk banks have rigid standards for screening and testing potential donors, for pasteurization, and for testing milk prior to distribution. ${ }^{58,59}$ Pasteurization is highly effective at decreasing the risk of transmission of HIV, CMV, Hepatitis B and Hepatitis C. The costs involved in establishing and maintaining a milk bank are considerable, however the feasibility of providing pasteurized donor milk in developing countries has been demonstrated. ${ }^{6}$ Unpasteurized donor milk has been advocated for premature infants in areas where religious beliefs preclude the use of milk from unknown donors. ${ }^{61,62}$ Further, "mother-to-mother milksharing" through internet-based communities is a rapidly growing practice in more than 50 countries, ${ }^{63}$ but health officials recommend against this practice due to safety risks, including lack of pasteurization, uncertain storage and shipping processes, and uncertain medication and substance use in the donor. ${ }^{64}$

Unfortunately, while pasteurization safeguards against transmission of infectious agents, it also has detrimental effects on the bioactive components of human milk. The currently recommended Holder pasteurization method (62.5 degrees $\mathrm{C}$ for 30 minutes) results in significant decreases in $\operatorname{sgA}$, lactoferrin, lysozyme, insulin-like growth factors, hepatocyte growth factor, water-soluble vitamins, bile salt-stimulated lipase, lipoprotein lipase, and anti-oxidant activity but does not decrease oligosaccharides, long-chain polyunsaturated fatty acids, gangliosides, lactose, fat-soluble vitamins, or epidermal growth factor. ${ }^{65-69}$ Holder pasteurization increases some medium chain saturated fatty acids, decreases some cytokines (TNFa, IFN $\gamma$, IL1 $\beta$, and IL10), and increases others (IL8). ${ }^{70}$ High temperature 
short-time pasteurization (72-75 degrees $\mathrm{C}$ for $15-16$ seconds) has been demonstrated to eliminate bacteria and many viruses ${ }^{71,72}$ with less protein loss (including maintenance of bile salt stimulating lipase, lactoferrin, and some IgAs), ${ }^{73}$ less severe loss of antioxidant activity, but greater loss of antimicrobial activity. ${ }^{66,74}$ In resource-poor countries, flash-heat treatment (temperature above 56 degress $C$ for 6 min 15 seconds) does not alter milk antibacterial activity against $E$. coli and $S$. aureus, only minimally decreases lactoferrin antibacterial activity, but significantly diminishes lysozyme antibacterial activity. ${ }^{75}$ Further research to determine the optimal pasteurization method to minimize risk and maximize bioactivity has great potential benefit for premature infants.

A fundamental concern is that the supply of donor human milk is currently limited. There are 11 milk banks in the U.S. and Canada that form the Human Milk Banking Association of North America (HMBANA, www.hmbana.org). In 2011 HMBANA milk banks distributed more than 2 million ounces of donor milk (a five fold increase from the year 2000), and the International Breast Milk Project (www.breastmilkproject.org) has distributed more than 280,000 ounces of donor milk to infants in South Africa since its founding in 2006, but such distributions represent only a fraction of the potential demand. The scarcity of this precious resource raises questions about how to increase the supply and equitably allocate human milk. ${ }^{76}$

\section{An "all human" diet for premature infants}

The development of a human milk fortifier formulated by concentrating pasteurized donor human milk and then adding vitamins and minerals has created the possibility of providing an "all-human diet" to premature infants. Various caloric densities of this fortifier allow for individual adjustment based on growth or blood urea nitrogen. A small study demonstrated a decrease in both moderate and severe NEC in small premature infants (birth weight $<1250$ g) receiving the "all-human diet." 77 Unfortunately this study was not adequately powered to study NEC as an outcome and the comparison group received formula if mother's milk supply was not adequate whereas the "all-human" infants received donor human milk in such a situation (i.e the increase in NEC in the comparison group could be related to either the powdered bovine human milk fortifier or the premature infant formula). This study underscores the fundamental question of whether components of human milk are protective against NEC or components of bovine milk somehow induce NEC. These two possibilities are, of course, not mutually exclusive. The cost of providing a fortifier made from donor human milk is significant. A recent cost-benefit analysis suggested that the savings in NEC prevention outweigh the costs of the "all-human" strategy, however this analysis was based on assumptions generated from the clinical trial described above and may therefore overestimate the protective effect of this approach. ${ }^{78}$ The ethical issues of marketing human milk for profit have recently been reviewed. ${ }^{76}$

\section{Improving breastfeeding rates for premature infants}

Premature labor and delivery are highly stressful to parents. Education regarding the importance and value of breastfeeding should begin during pregnancy and be reemphasized when premature delivery seems likely. As noted above, pumping with an electric pump should be initiated within 6-12 hours of delivery and continued 8-12 times per 24 hours until the milk supply is well established ${ }^{45}$ Reassurance and encouragement are valuable as new mothers are often worried and discouraged by the initial small volumes obtained. Early assistance by a nurse or lactation consultant is helpful in establishing an effective pumping regimen. Regular questioning by the NICU nurse or physician regarding milk supply is valuable to encourage early intervention when milk production decreases. Milk production 
decreases with maternal depression and increases with increased frequency of pumping and time spent skin-to-skin with the premature infant. ${ }^{79}$

Parents should be instructed in the proper labeling, storage and transport of milk so that milk pumped at home arrives frozen in the NICU. Color-coded labeling of colostrum to ensure its early/immediate use is valuable. Recent studies demonstrate that human milk is stable upon thawing in a 4 degree $\mathrm{C}$ refrigerator for 96 hours and does not need to be discarded after 24 or 72 hours as previously practiced.$^{80}$ Freezing and thawing of human milk may rupture fat globules leading to adherence of lipid to plastic surfaces. For this reason, there may be benefit in avoiding continuous feedings of human milk when possible and positioning syringe pumps so that the syringe is near vertical. ${ }^{81}$

Differences in nutrient content between foremilk and hindmilk are well established. Hindmilk from women delivering preterm is higher in protein, fatty acids, energy, and fat soluble vitamins than foremilk. ${ }^{82,83}$ The practice of discarding the foremilk and feeding premature infants predominantly hindmilk has been shown to increase weight gain. ${ }^{84,85}$ Hindmilk has higher viscosity and may be more difficult to express with an electric pump. The combination of hand expression and electric pumping has been shown to increase milk production ${ }^{86}$ and fat content of expressed milk. ${ }^{87}$ The benefits of increased hindmilk include not only increased calories but increased polyunsaturated fats and increased absorption of fat soluble vitamins.

It is common for women delivering prematurely to experience a decrease in milk production. Interventions to increase production include increased skin-to-skin time, stress reduction, careful attention to diet, sleep, and pumping schedule, and medications. ${ }^{88}$ Domperidone is effective in increasing milk production. ${ }^{89,90}$ Metoclopramide has also been studied as a galactogogue, however studies to date are of limited quality and enthusiasm for this product is dampened by concerns about tardive dyskinesia. Herbal galactagogues are popular with more than $15 \%$ of lactating women reporting use. Fenugreek (Trigonella foenumgraexum) is widely used with several anecdotal reports of increased milk supply within 24 to 72 hours in most women. ${ }^{91}$ Two small randomized blinded placebo controlled trials are available in the medical literature. The first showed no difference in milk supply in women receiving capsules of fenugreek compared to the reference group. ${ }^{92}$ The second showed an increase in milk production of almost double in women receiving tea containing fenugreek, fennel, raspberry leaf and goat's rue compared to a placebo tea. ${ }^{93}$ Maternal side effects include nausea, diarrhea, and exacerbation of asthma. Since fenugreek is a member of the pea family, mothers allergic to chickpeas, soybeans, or peanuts should avoid this remedy. It is worth noting that fenugreek can impart a maple syrup odor to the sweat and urine of both mother and infant. Studies of milk composition and amount of fenugreek in expressed milk have not been published. Milk thistle (Silbum marianum) has been demonstrated in a placebocontrolled trial to almost double milk production with no change in nutrient content of the milk or detectable levels of the active ingredient (silymarin). ${ }^{94}$ Side effects appear to be rare and include nausea, diarrhea, and anaphylaxis. Shatavari (dried powdered Asparagus racemosus root) has been studied in two randomized placebocontrolled blinded studies with one study demonstrating increased maternal prolactin levels and increased infant weight gain ${ }^{95}$ and the other showing no benefit. ${ }^{96}$ Side effects include runny nose, conjunctivitis, and contact dermatitis. Torbangun leaves (Coleus amboinicus Lour) added to a soup increased milk production in a randomized blinded placebocontrolled trial, ${ }^{92}$ however side effects were not mentioned and a commercial preparation is not available. Evidence of safety and efficacy of other herbal galactogogues including blessed thistle, fennel, and chasteberry is lacking. Detailed reviews of the existing data for herbal galactogogues are available. ${ }^{88,97}$ 
Successful transition from tube feedings to breast feeding can be challenging. Skin-to-skin care begun as soon as the baby is stable improves hemodynamic stability without increasing energy expenditure. ${ }^{98,99}$ Non-nutritive sucking (mother pumps first and then places the baby to the breast) can be attempted as soon as the baby is extubated and stable with success noted as early as 28 weeks corrected gestational age. ${ }^{100}$ Most premature infants can begin nutritive sucking about 32 weeks gestation. Assistance from an experienced nurse or lactation consultant is invaluable. Positioning that supports the mother's breast and the baby's head and neck are essential with the cross-cradle and football holds most effective. Early use of nipple shields increases milk intake and duration of breastfeeding. ${ }^{101}$

\section{Withholding mother's own milk from premature infants}

In most instances provision of mother's own milk is optimal. The few circumstances in which mother's own milk should not be provided are discussed in Chapter 15, Circumstances when breastfeeding is contraindicated. While it is certainly plausible that premature infants with their immature immune systems are more vulnerable to infection, in most cases data regarding differences between premature and term infants in susceptibility to milk-associated infections are lacking. This section will focus on contraindications specific to premature infants.

Post-natal transmission of cytomegalovirus (CMV) through breast milk is a frequent occurrence given that approximately $50 \%$ of adults are carriers of CMV. Symptomatic postnatal CMV infection is rare in term infants, likely because of maternal antibody transfer in the third trimester. A recent meta-analysis found wide variation among studies with overall mean rate of CMV transmission via breast milk 23\%, mean risk of symptomatic CMV infection $3.7 \%$ and mean risk of sepsis-like symptoms of $0.7 \%$ with most symptomatic infections in premature infants. ${ }^{102}$ Low birth weight and early transmission after birth are risk factors for symptomatic disease. ${ }^{103}$ Whether CMV infection increases the severity of the diseases of prematurity (e.g. chronic lung disease, NEC, periventricular leukomalacia) is unknown. Long term studies of premature infants infected with CMV through mother's own milk are few, but suggest that hearing loss and severe neurodevelopmental delays are uncommon. ${ }^{104,105}$ Pasteurization inactivates CMV; freezing may decrease but does not eliminate transmission of CMV. ${ }^{106}$ There is no consensus among neonatologists and pediatricians regarding the best balance between the benefits of human milk and the risks of CMV infection. Recommendations vary from pasteurizing all human milk until corrected gestational age of 32 weeks, to screening all mothers who deliver preterm and withholding colostrum and pasteurizing milk of women who are CMV IgG positive, to freezing all CMV positive milk for premature infants $<32$ weeks.

Drug abuse is common among pregnant and nursing women and increases the risk of premature delivery. ${ }^{107,108}$ Long term effects of in utero and post natal exposure to these substances are unclear, but studies to date are concerning. ${ }^{109,} 110$ Whether the risks of continued exposure to these substances outweigh the benefits of human milk for the premature infant with its rapidly developing central nervous system is unclear. Current guidelines are to encourage mothers who abuse substances other than opiates to obtain counseling and to refrain from providing milk for their infants until they are free of the abused drugs. ${ }^{111}$

Treatment of depression in pregnancy and in breastfeeding women is an area of particular relevance given the reported associations between maternal anti-depressant use and pre-term labor, ${ }^{112}$ neonatal seizures, ${ }^{112}$ and neonatal primary pulmonary hypertension. Causality and the mechanisms underlying these associations are unknown. It is unclear whether the latter association in a small number of studies is related to the medications or to risk factors 
associated with both maternal depression and pulmonary hypertension (e.g. obesity, smoking, prematurity, and cesarean delivery). ${ }^{113} \mathrm{~A}$ recent review of anti-depressant medication use in lactating women suggested caution in the use of fluoxetine and avoidance of doxepine and nefazodone. ${ }^{114}$ Data specific to preterm infants or neonates with pulmonary hypertension are not available.

It is likely that in situations where mother's own milk should not be given, donor human milk would be advantageous. There are rare exceptions wherein an infant should receive no (e.g. galactosemia) or limited volumes (e.g. some inborn errors of metabolism and human milk protein intolerance) of human milk. These are particularly relevant to premature infants in whom the brain is developing rapidly.

\section{Conclusion}

Fortified human milk has tremendous benefits in improving the growth and short and long term outcomes for the premature infant. Mother's own milk has clear advantages to donor human milk both due to its composition and the lack of necessity for pasteurization. Increased efforts to establish and maintain milk supply in women delivering preterm are likely to have greater benefits than providing pasteurized donor human milk. Improved pasteurization protocols and carefully performed trials of galactogogues may be of particular value to this highly vulnerable population.

\section{Acknowledgments}

Disclosure:

Funding sources: Eunice K. Shriver National Institute of Child Health and Human Development Grant HD059127. The author has received nutritional products from Prolacta Bioscience for clinical trials.

\section{References}

1. Martin J, Hamilton B, Ventura S, Osterman M, Wilson E, Mathews T. Births: final data for 2010. Natl Vital Stat Rep. 2012; 61(1)

2. Underwood MA, Gilbert WM, Sherman MP. Amniotic fluid: not just fetal urine anymore. J Perinatol. 2005 May; 25(5):341-348. [PubMed: 15861199]

3. Pitkin RM, Reynolds WA. Fetal ingestion and metabolism of amniotic fluid protein. Am J Obstet Gynecol. 1975 Oct 15; 123(4):356-363. [PubMed: 810026]

4. Cellini C, Xu J, Buchmiller TL. Effect of esophageal ligation on small intestinal development in normal and growth-retarded fetal rabbits. J Pediatr Gastroenterol Nutr. 2006 Sep; 43(3):291-298. [PubMed: 16954949]

5. Burjonrappa SC, Crete E, Bouchard S. The role of amniotic fluid in influencing neonatal birth weight. J Perinatol. 2010 Jan; 30(1):27-29. [PubMed: 19626029]

6. de Figueiredo CS, Palhares DB, Melnikov P, Moura AJ, dos Santos SC. Zinc and copper concentrations in human preterm milk. Biol Trace Elem Res. 2010 Jul; 136(1):1-7. [PubMed: 19774349]

7. O'Brien CE, Krebs NF, Westcott JL, Dong F. Relationships among plasma zinc, plasma prolactin, milk transfer, and milk zinc in lactating women. J Hum Lact. 2007 May; 23(2):179-183. [PubMed: 17478870]

8. Ruhaak LR, Lebrilla CB. Advances in analysis of human milk oligosaccharides. Adv Nutr. 2012 May; 3(3):406S-414S. [PubMed: 22585919]

9. Sela DA, Mills DA. Nursing our microbiota: molecular linkages between bifidobacteria and milk oligosaccharides. Trends Microbiol. 2010 Jul; 18(7):298-307. [PubMed: 20409714] 
10. Coppa GV, Gabrielli O, Zampini L, et al. Oligosaccharides in 4 different milk groups, Bifidobacteria, and Ruminococcus obeum. J Pediatr Gastroenterol Nutr. 2011 Jul; 53(1):80-87. [PubMed: 21478759]

11. Newburg DS, Ruiz-Palacios GM, Morrow AL. Human milk glycans protect infants against enteric pathogens. Annu Rev Nutr. 2005; 25:37-58. [PubMed: 16011458]

12. Bode L. Human Milk Oligosaccharides: Every Baby needs a Sugar Mama. Glycobiology. 2012 Apr 18.

13. Gabrielli O, Zampini L, Galeazzi T, et al. Preterm milk oligosaccharides during the first month of lactation. Pediatrics. 2011 Dec; 128(6):e1520-e1531. [PubMed: 22123889]

14. De Leoz ML, Gaerlan SC, Strum JS, et al. Lacto-N-Tetraose, Fucosylation, and Secretor Status Are Highly Variable in Human Milk Oligosaccharides From Women Delivering Preterm. J Proteome Res. 2012 Aug 28.

15. Coppa GV, Gabrielli O, Zampini L, et al. Glycosaminoglycan content in term and preterm milk during the first month of lactation. Neonatology. 2012; 101(1):74-76. [PubMed: 21934331]

16. Eilers E, Ziska T, Harder T, Plagemann A, Obladen M, Loui A. Leptin determination in colostrum and early human milk from mothers of preterm and term infants. Early Hum Dev. 2011 Jun; 87(6): 415-419. [PubMed: 21482454]

17. Freed LM, Berkow SE, Hamosh P, York CM, Mehta NR, Hamosh M. Lipases in human milk: effect of gestational age and length of lactation on enzyme activity. J Am Coll Nutr. 1989 Apr; 8(2):143-150. [PubMed: 2708730]

18. American Academy of Pediatrics SoB. Breastfeeding and the use of Human Milk. Pediatrics. 2012; 129:e827-e841. [PubMed: 22371471]

19. Schanler RJ, Shulman RJ, Lau C. Feeding strategies for premature infants: beneficial outcomes of feeding fortified human milk versus preterm formula. Pediatrics. 1999 Jun; 103(6 Pt 1):11501157. [PubMed: 10353922]

20. Sisk PM, Lovelady CA, Dillard RG, Gruber KJ, O'Shea TM. Early human milk feeding is associated with a lower risk of necrotizing enterocolitis in very low birth weight infants. $\mathrm{J}$ Perinatol. 2007 Jul; 27(7):428-433. [PubMed: 17443195]

21. Meinzen-Derr J, Poindexter B, Wrage L, Morrow AL, Stoll B, Donovan EF. Role of human milk in extremely low birth weight infants' risk of necrotizing enterocolitis or death. J Perinatol. 2009 Jan; 29(1):57-62. [PubMed: 18716628]

22. Okamoto T, Shirai M, Kokubo M, et al. Human milk reduces the risk of retinal detachment in extremely low-birthweight infants. Pediatr Int. 2007 Dec; 49(6):894-897. [PubMed: 18045292]

23. Maayan-Metzger A, Avivi S, Schushan-Eisen I, Kuint J. Human milk versus formula feeding among preterm infants: short-term outcomes. Am J Perinatol. 2012 Feb; 29(2):121-126. [PubMed: 22094917]

24. Vohr BR, Poindexter BB, Dusick AM, et al. Beneficial effects of breast milk in the neonatal intensive care unit on the developmental outcome of extremely low birth weight infants at 18 months of age. Pediatrics. 2006 Jul; 118(1):e115-e123. [PubMed: 16818526]

25. Isaacs EB, Fischl BR, Quinn BT, Chong WK, Gadian DG, Lucas A. Impact of breast milk on intelligence quotient, brain size, and white matter development. Pediatr Res. 2010 Apr; 67(4):357362. [PubMed: 20035247]

26. Vohr BR, Poindexter BB, Dusick AM, et al. Persistent beneficial effects of breast milk ingested in the neonatal intensive care unit on outcomes of extremely low birth weight infants at 30 months of age. Pediatrics. 2007 Oct; 120(4):e953-e959. [PubMed: 17908750]

27. Singhal A, Cole TJ, Lucas A. Early nutrition in preterm infants and later blood pressure: two cohorts after randomised trials. Lancet. 2001 Feb 10; 357(9254):413-419. [PubMed: 11273059]

28. Singhal A, Cole TJ, Fewtrell M, Lucas A. Breastmilk feeding and lipoprotein profile in adolescents born preterm: follow-up of a prospective randomised study. Lancet. 2004 May 15; 363(9421): 1571-1578. [PubMed: 15145629]

29. Singhal A, Farooqi IS, O'Rahilly S, Cole TJ, Fewtrell M, Lucas A. Early nutrition and leptin concentrations in later life. Am J Clin Nutr. 2002 Jun; 75(6):993-999. [PubMed: 12036804] 
30. Hintz SR, Kendrick DE, Stoll BJ, et al. Neurodevelopmental and growth outcomes of extremely low birth weight infants after necrotizing enterocolitis. Pediatrics. 2005 Mar; 115(3):696-703. [PubMed: 15741374]

31. Furman L, Taylor G, Minich N, Hack M. The effect of maternal milk on neonatal morbidity of very low-birth-weight infants. Arch Pediatr Adolesc Med. 2003 Jan; 157(1):66-71. [PubMed: 12517197]

32. Manzoni P, Rinaldi M, Cattani S, et al. Bovine lactoferrin supplementation for prevention of lateonset sepsis in very low-birth-weight neonates: a randomized trial. Jama. 2009 Oct 7; 302(13): 1421-1428. [PubMed: 19809023]

33. Dvorak B. Milk epidermal growth factor and gut protection. J Pediatr. 2010 Feb; 156 (2 Suppl):S31-35. [PubMed: 20105663]

34. Jantscher-Krenn E, Zherebtsov M, Nissan C, et al. The human milk oligosaccharide disialyllacto$\mathrm{N}$-tetraose prevents necrotising enterocolitis in neonatal rats. Gut. 2011 Dec 3.

35. Wang Y, Hoenig JD, Malin KJ, et al. 16S rRNA gene-based analysis of fecal microbiota from preterm infants with and without necrotizing enterocolitis. Isme J. 2009 Aug; 3(8):944-954. [PubMed: 19369970]

36. Mai V, Young CM, Ukhanova M, et al. Fecal microbiota in premature infants prior to necrotizing enterocolitis. PLoS One. 2011; 6(6):e20647. [PubMed: 21674011]

37. Adlerberth I, Wold AE. Establishment of the gut microbiota in Western infants. Acta Paediatr. 2009 Feb; 98(2):229-238. [PubMed: 19143664]

38. Cilieborg MS, Boye M, Sangild PT. Bacterial colonization and gut development in preterm neonates. Early Hum Dev. 2012 Mar; 88(Suppl 1):S41-49. [PubMed: 22284985]

39. Poroyko V, Morowitz M, Bell T, et al. Diet creates metabolic niches in the "immature gut" that shape microbial communities. Nutr Hosp. 2011 Nov-Dec;26(6):1283-1295. [PubMed: 22411374]

40. Zachariassen G, Faerk J, Esberg BH, et al. Allergic diseases among very preterm infants according to nutrition after hospital discharge. Pediatr Allergy Immunol. 2011 Aug; 22(5):515-520. [PubMed: 21332800]

41. Rodriguez NA, Meier PP, Groer MW, Zeller JM. Oropharyngeal administration of colostrum to extremely low birth weight infants: theoretical perspectives. J Perinatol. 2009 Jan; 29(1):1-7. [PubMed: 18769379]

42. Montjaux-Regis N, Cristini C, Arnaud C, Glorieux I, Vanpee M, Casper C. Improved growth of preterm infants receiving mother's own raw milk compared with pasteurized donor milk. Acta Paediatr. 2011 Dec; 100(12):1548-1554. [PubMed: 21707744]

43. Quigley MA, Henderson G, Anthony MY, McGuire W. Formula milk versus donor breast milk for feeding preterm or low birth weight infants. Cochrane Database Syst Rev. 2007; (4):CD002971. [PubMed: 17943776]

44. Schanler RJ, Lau C, Hurst NM, Smith EO. Randomized trial of donor human milk versus preterm formula as substitutes for mothers' own milk in the feeding of extremely premature infants. Pediatrics. 2005 Aug; 116(2):400-406. [PubMed: 16061595]

45. Spatz DL. Ten steps for promoting and protecting breastfeeding for vulnerable infants. J Perinat Neonatal Nurs. 2004 Oct-Dec;18(4):385-396. [PubMed: 15646308]

46. Kashyap S, Schulze KF, Forsyth M, Dell RB, Ramakrishnan R, Heird WC. Growth, nutrient retention, and metabolic response of low-birth-weight infants fed supplemented and unsupplemented preterm human milk. Am J Clin Nutr. 1990 Aug; 52(2):254-262. [PubMed: 2375291]

47. Kuschel CA, Harding JE. Multicomponent fortified human milk for promoting growth in preterm infants. Cochrane Database Syst Rev. 2004; (1):CD000343. [PubMed: 14973953]

48. Premji SS, Fenton TR, Sauve RS. Higher versus lower protein intake in formulafed low birth weight infants. Cochrane Database Syst Rev. 2006; (1):CD003959. [PubMed: 16437468]

49. Weber A, Loui A, Jochum F, Buhrer C, Obladen M. Breast milk from mothers of very low birthweight infants: variability in fat and protein content. Acta Paediatr. 2001 Jul; 90(7):772-775. [PubMed: 11519980]

50. Arslanoglu S, Moro GE, Ziegler EE. Preterm infants fed fortified human milk receive less protein than they need. J Perinatol. 2009 Jul; 29(7):489-492. [PubMed: 19444237] 
51. Polberger S, Raiha NC, Juvonen P, Moro GE, Minoli I, Warm A. Individualized protein fortification of human milk for preterm infants: comparison of ultrafiltrated human milk protein and a bovine whey fortifier. J Pediatr Gastroenterol Nutr. 1999 Sep; 29(3):332-338. [PubMed: 10468001]

52. Arslanoglu S, Moro GE, Ziegler EE. Adjustable fortification of human milk fed to preterm infants: does it make a difference? J Perinatol. 2006 Oct; 26(10):614-621. [PubMed: 16885989]

53. Miller J, Makrides M, Gibson RA, et al. Effect of increasing protein content of human milk fortifier on growth in preterm infants born at <31 wk gestation: a randomized controlled trial. Am J Clin Nutr. 2012 Mar; 95(3):648-655. [PubMed: 22301933]

54. Rochow N, Jochum F, Redlich A, et al. Fortification of breast milk in VLBW infants: metabolic acidosis is linked to the composition of fortifiers and alters weight gain and bone mineralization. Clin Nutr. 2011 Feb; 30(1):99-105. [PubMed: 20727626]

55. Friel JK, Diehl-Jones B, Cockell KA, et al. Evidence of oxidative stress in relation to feeding type during early life in premature infants. Pediatr Res. 2011 Feb; 69(2):160-164. [PubMed: 21045751]

56. Reich F, Konig R, von Wiese W, Klein G. Prevalence of Cronobacter spp. in a powdered infant formula processing environment. Int J Food Microbiol. 2010 Jun 15; 140(2-3):214-217. [PubMed: 20409601]

57. Friedemann M. Epidemiology of invasive neonatal Cronobacter (Enterobacter sakazakii) infections. Eur J Clin Microbiol Infect Dis. 2009 Nov; 28(11):1297-1304. [PubMed: 19662446]

58. Guidelines for the establishment and operation of a donor human milk bank. http:// www.hmbana.org/

59. Center for Clinical Practice NIfHaCE. Donor Breast Milk Banks: The Operation of Donor Milk Bank Services. 2010 Feb.

60. Coutsoudis I, Adhikari M, Nair N, Coutsoudis A. Feasibility and safety of setting up a donor breastmilk bank in a neonatal prem unit in a resource limited setting: An observational, longitudinal cohort study. BMC Public Health. 2011; 11:356. [PubMed: 21599983]

61. al-Naqeeb NA, Azab A, Eliwa MS, Mohammed BY. The introduction of breast milk donation in a Muslim country. J Hum Lact. 2000 Nov; 16(4):346-350. [PubMed: 11155613]

62. Hsu HT, Fong TV, Hassan NM, Wong HL, Rai JK, Khalid Z. Human milk donation is an alternative to human milk bank. Breastfeed Med. 2012 Apr; 7(2):118-122. [PubMed: 22011131]

63. Akre JE, Gribble KD, Minchin M. Milk sharing: from private practice to public pursuit. Int Breastfeed J. 2011; 6:8. [PubMed: 21702986]

64. Use of donor human milk. 2012. [http:/ / www.fda.gov/ ScienceResearch/ SpecialTopics/ PediatricTherapeuticsResearch/ ucm235203.htm]

65. Ewaschuk JB, Unger S, Harvey S, O'Connor DL, Field CJ. Effect of pasteurization on immune components of milk: implications for feeding preterm infants. Appl Physiol Nutr Metab. 2011 Apr; 36(2):175-182. [PubMed: 21609278]

66. Silvestre D, Miranda M, Muriach M, Almansa I, Jareno E, Romero FJ. Antioxidant capacity of human milk: effect of thermal conditions for the pasteurization. Acta Paediatr. 2008 Aug; 97(8): 1070-1074. [PubMed: 18477059]

67. Bertino E, Coppa GV, Giuliani F, et al. Effects of Holder pasteurization on human milk oligosaccharides. Int J Immunopathol Pharmacol. 2008 Apr-Jun;21(2):381-385. [PubMed: 18547467]

68. Goelz R, Hihn E, Hamprecht K, et al. Effects of different CMV-heat-inactivationmethods on growth factors in human breast milk. Pediatr Res. 2009 Apr; 65(4):458-461. [PubMed: 19127217]

69. Van Zoeren-Grobben D, Schrijver J, Van den Berg H, Berger HM. Human milk vitamin content after pasteurisation, storage, or tube feeding. Arch Dis Child. 1987 Feb; 62(2):161-165. [PubMed: 3103547]

70. Ewaschuk JB, Unger S, O'Connor DL, et al. Effect of pasteurization on selected immune components of donated human breast milk. J Perinatol. 2011 Sep; 31(9):593-598. [PubMed: 21330996]

71. Goldblum RM, Dill CW, Albrecht TB, Alford ES, Garza C, Goldman AS. Rapid high-temperature treatment of human milk. J Pediatr. 1984 Mar; 104(3):380-385. [PubMed: 6323663] 
72. Terpstra FG, Rechtman DJ, Lee ML, et al. Antimicrobial and antiviral effect of high-temperature short-time (HTST) pasteurization applied to human milk. Breastfeed Med. 2007 Mar; 2(1):27-33. [PubMed: 17661617]

73. Baro C, Giribaldi M, Arslanoglu S, et al. Effect of two pasteurization methods on the protein content of human milk. Front Biosci (Elite Ed). 2011; 3:818-829. [PubMed: 21622093]

74. Silvestre D, Ruiz P, Martinez-Costa C, Plaza A, Lopez MC. Effect of pasteurization on the bactericidal capacity of human milk. J Hum Lact. 2008 Nov; 24(4):371-376. [PubMed: 18784324]

75. Chantry CJ, Wiedeman J, Buehring G, et al. Effect of flash-heat treatment on antimicrobial activity of breastmilk. Breastfeed Med. 2011 Jun; 6(3):111-116. [PubMed: 21091243]

76. Miracle DJ, Szucs KA, Torke AM, Helft PR. Contemporary ethical issues in human milk-banking in the United States. Pediatrics. 2011 Dec; 128(6):1186-1191. [PubMed: 22084324]

77. Sullivan S, Schanler RJ, Kim JH, et al. An exclusively human milk-based diet is associated with a lower rate of necrotizing enterocolitis than a diet of human milk and bovine milk-based products. $\mathrm{J}$ Pediatr. 2010 Apr; 156(4):562-567 e561. [PubMed: 20036378]

78. Ganapathy V, Hay JW, Kim JH. Costs of necrotizing enterocolitis and costeffectiveness of exclusively human milk-based products in feeding extremely premature infants. Breastfeed Med. 2012 Feb; 7(1):29-37. [PubMed: 21718117]

79. Lau C, Hurst NM, Smith EO, Schanler RJ. Ethnic/racial diversity, maternal stress, lactation and very low birthweight infants. J Perinatol. 2007 Jul; 27(7):399-408. [PubMed: 17592486]

80. Slutzah M, Codipilly CN, Potak D, Clark RM, Schanler RJ. Refrigerator storage of expressed human milk in the neonatal intensive care unit. J Pediatr. 2010 Jan; 156(1):26-28. [PubMed: 19783003]

81. Brennan-Behm M, Carlson GE, Meier P, Engstrom J. Caloric loss from expressed mother's milk during continuous gavage infusion. Neonatal Netw. 1994 Mar; 13(2):27-32. [PubMed: 8139519]

82. Charpak N, Ruiz JG. Breast milk composition in a cohort of pre-term infants' mothers followed in an ambulatory programme in Colombia. Acta Paediatr. 2007 Dec; 96(12):1755-1759. [PubMed: 17931396]

83. Bishara R, Dunn MS, Merko SE, Darling P. Nutrient composition of hindmilk produced by mothers of very low birth weight infants born at less than 28 weeks' gestation. J Hum Lact. 2008 May; 24(2):159-167. [PubMed: 18436967]

84. Valentine CJ, Hurst NM, Schanler RJ. Hindmilk improves weight gain in lowbirth- weight infants fed human milk. J Pediatr Gastroenterol Nutr. 1994 May; 18(4):474-477. [PubMed: 8071785]

85. Ogechi AA, William O, Fidelia BT. Hindmilk and weight gain in preterm very low-birthweight infants. Pediatr Int. 2007 Apr; 49(2):156-160. [PubMed: 17445031]

86. Morton J, Hall JY, Wong RJ, Thairu L, Benitz WE, Rhine WD. Combining hand techniques with electric pumping increases milk production in mothers of preterm infants. J Perinatol. 2009 Nov; 29(11):757-764. [PubMed: 19571815]

87. Morton J, Wong RJ, Hall JY, et al. Combining hand techniques with electric pumping increases the caloric content of milk in mothers of preterm infants. J Perinatol. 2012 Jan 5.

88. Jackson PC. Complementary and alternative methods of increasing breast milk supply for lactating mothers of infants in the NICU. Neonatal Netw. 2010 Jul-Aug;29(4):225-230. [PubMed: 20630837]

89. Donovan TJ, Buchanan K. Medications for increasing milk supply in mothers expressing breastmilk for their preterm hospitalised infants. Cochrane Database Syst Rev. 2012; 3:CD005544. [PubMed: 22419310]

90. Gabay MP. Galactogogues: medications that induce lactation. J Hum Lact. 2002 Aug; 18(3):274279. [PubMed: 12192964]

91. Huggins, K. Fenugreek: one remedy for low milk production. 2012. http:// www.breastfeedingonline.com/fenuhugg.shtmlhttp://www.breastfeedingonline.com/ fenuhugg.shtml

92. Damanik R, Wahlqvist ML, Wattanapenpaiboon N. Lactagogue effects of Torbangun, a Bataknese traditional cuisine. Asia Pac J Clin Nutr. 2006; 15(2):267-274. [PubMed: 16672214] 
93. Turkyilmaz C, Onal E, Hirfanoglu IM, et al. The effect of galactagogue herbal tea on breast milk production and short-term catch-up of birth weight in the first week of life. J Altern Complement Med. 2011 Feb; 17(2):139-142. [PubMed: 21261516]

94. Di Pierro F, Callegari A, Carotenuto D, Tapia MM. Clinical efficacy, safety and tolerability of BIO-C (micronized Silymarin) as a galactagogue. Acta Biomed. 2008 Dec; 79(3):205-210. [PubMed: 19260380]

95. Gupta M, Shaw B. A double-blind randomized clinical trial for evaluation of galactogogue activity of asparagus racemosus wild. Iranian J Pharm Res. 2011; 10(1):167-172.

96. Sharma S, Ramji S, Kumari S, Bapna JS. Randomized controlled trial of Asparagus racemosus (Shatavari) as a lactogogue in lactational inadequacy. Indian Pediatr. 1996 Aug; 33(8):675-677. [PubMed: 8979551]

97. Zapantis A, Steinberg JG, Schilit L. Use of herbals as galactagogues. J Pharm Pract. 2012 Apr; 25(2):222-231. [PubMed: 22392841]

98. Fohe K, Kropf S, Avenarius S. Skin-to-skin contact improves gas exchange in premature infants. J Perinatol. 2000 Jul-Aug;20(5):311-315. [PubMed: 10920790]

99. Bauer J, Sontheimer D, Fischer C, Linderkamp O. Metabolic rate and energy balance in very low birth weight infants during kangaroo holding by their mothers and fathers. J Pediatr. 1996 Oct; 129(4):608-611. [PubMed: 8859271]

100. Nyqvist KH, Sjoden PO, Ewald U. The development of preterm infants' breastfeeding behavior. Early Hum Dev. 1999 Jul; 55(3):247-264. [PubMed: 10463789]

101. Meier PP, Brown LP, Hurst NM, et al. Nipple shields for preterm infants: effect on milk transfer and duration of breastfeeding. J Hum Lact. 2000 May; 16(2):106-114. quiz 129-131. [PubMed: 11153341]

102. Kurath S, Halwachs-Baumann G, Muller W, Resch B. Transmission of cytomegalovirus via breast milk to the prematurely born infant: a systematic review. Clin Microbiol Infect. 2010 Aug; 16(8):1172-1178. [PubMed: 20670291]

103. Hamprecht K, Maschmann J, Jahn G, Poets CF, Goelz R. Cytomegalovirus transmission to preterm infants during lactation. J Clin Virol. 2008 Mar; 41(3):198-205. [PubMed: 18243784]

104. Bevot A, Hamprecht K, Krageloh-Mann I, Brosch S, Goelz R, Vollmer B. Longterm outcome in preterm children with human cytomegalovirus infection transmitted via breast milk. Acta Paediatr. 2012 Apr; 101(4):e167-e172. [PubMed: 22111513]

105. Bryant P, Morley C, Garland S, Curtis N. Cytomegalovirus transmission from breast milk in premature babies: does it matter? Arch Dis Child Fetal Neonatal Ed. 2002 Sep; 87(2):F75-F77. [PubMed: 12193509]

106. Maschmann J, Hamprecht K, Weissbrich B, Dietz K, Jahn G, Speer CP. Freezethawing of breast milk does not prevent cytomegalovirus transmission to a preterm infant. Arch Dis Child Fetal Neonatal Ed. 2006 Jul; 91(4):F288-F290. [PubMed: 16790732]

107. Hayatbakhsh MR, Flenady VJ, Gibbons KS, et al. Birth outcomes associated with cannabis use before and during pregnancy. Pediatr Res. 2012 Feb; 71(2):215-219. [PubMed: 22258135]

108. Gouin K, Murphy K, Shah PS. Effects of cocaine use during pregnancy on low birthweight and preterm birth: systematic review and metaanalyses. Am J Obstet Gynecol. 2011 Apr; 204(4):340 e341-312. [PubMed: 21257143]

109. Bandstra ES, Morrow CE, Accornero VH, Mansoor E, Xue L, Anthony JC. Estimated effects of in utero cocaine exposure on language development through early adolescence. Neurotoxicol Teratol. 2011 Jan-Feb;33(1):25-35. [PubMed: 21256422]

110. Ackerman JP, Riggins T, Black MM. A review of the effects of prenatal cocaine exposure among school-aged children. Pediatrics. 2010 Mar; 125(3):554-565. [PubMed: 20142293]

111. Transfer of drugs and other chemicals into human milk. Pediatrics. 2001 Sep; 108(3):776-789. [PubMed: 11533352]

112. Hayes RM, Wu P, Shelton RC, et al. Maternal antidepressant use and adverse outcomes: a cohort study of 228,876 pregnancies. Am J Obstet Gynecol. 2012 Jul; 207(1):49 e41-49. [PubMed: 22727349] 
113. Occhiogrosso M, Omran SS, Altemus M. Persistent pulmonary hypertension of the newborn and selective serotonin reuptake inhibitors: lessons from clinical and translational studies. Am J Psychiatry. 2012 Feb; 169(2):134-140. [PubMed: 22420034]

114. Davanzo R, Copertino M, De Cunto A, Minen F, Amaddeo A. Antidepressant drugs and breastfeeding: a review of the literature. Breastfeed Med. 2011 Apr; 6(2):89-98. [PubMed: 20958101]

115. Bauer J, Gerss J. Longitudinal analysis of macronutrients and minerals in human milk produced by mothers of preterm infants. Clin Nutr. 2011 Apr; 30(2):215-220. [PubMed: 20801561]

116. Molto-Puigmarti C, Castellote AI, Carbonell-Estrany X, Lopez-Sabater MC. Differences in fat content and fatty acid proportions among colostrum, transitional, and mature milk from women delivering very preterm, preterm, and term infants. Clin Nutr. $2011 \mathrm{Feb}$; 30(1):116-123. [PubMed: 20800325]

117. Chuang CK, Lin SP, Lee HC, et al. Free amino acids in full-term and pre-term human milk and infant formula. J Pediatr Gastroenterol Nutr. 2005 Apr; 40(4):496-500. [PubMed: 15795601]

118. Friel JK, Andrews WL, Jackson SE, et al. Elemental composition of human milk from mothers of premature and full-term infants during the first 3 months of lactation. Biol Trace Elem Res. 1999 Mar; 67(3):225-247. [PubMed: 10201330]

119. Coppa GV, Gabrielli O, Pierani P, Catassi C, Carlucci A, Giorgi PL. Changes in carbohydrate composition in human milk over 4 months of lactation. Pediatrics. 1993 Mar; 91(3):637-641. [PubMed: 8441573]

120. Mehta R, Petrova A. Biologically active breast milk proteins in association with very preterm delivery and stage of lactation. J Perinatol. 2011 Jan; 31(1):58-62. [PubMed: 20523299]

121. Castellote C, Casillas R, Ramirez-Santana C, et al. Premature delivery influences the immunological composition of colostrum and transitional and mature human milk. J Nutr. 2011 Jun; 141(6):1181-1187. [PubMed: 21508211]

122. Dvorak B, Fituch CC, Williams CS, Hurst NM, Schanler RJ. Increased epidermal growth factor levels in human milk of mothers with extremely premature infants. Pediatr Res. 2003 Jul; 54(1): 15-19. [PubMed: 12646719] 


\section{Key points}

1. Fortified mother's own milk is the optimal diet for the premature infant to maximize growth, development, and protection against necrotizing enterocolitis and infection.

2. Fortified pasteurized human donor milk is recommended by the American Academy of Pediatrics Section on Breastfeeding as the preferred alternative for premature infants whose mothers are unable to provide a sufficient volume of their own milk.

3. Pasteurized donor human milk does not provide the same nutrient or biologically active molecules as unpasteurized own mother's milk.

4. Careful attention to establishing and maintaining milk production in women delivering preterm has significant benefits. 

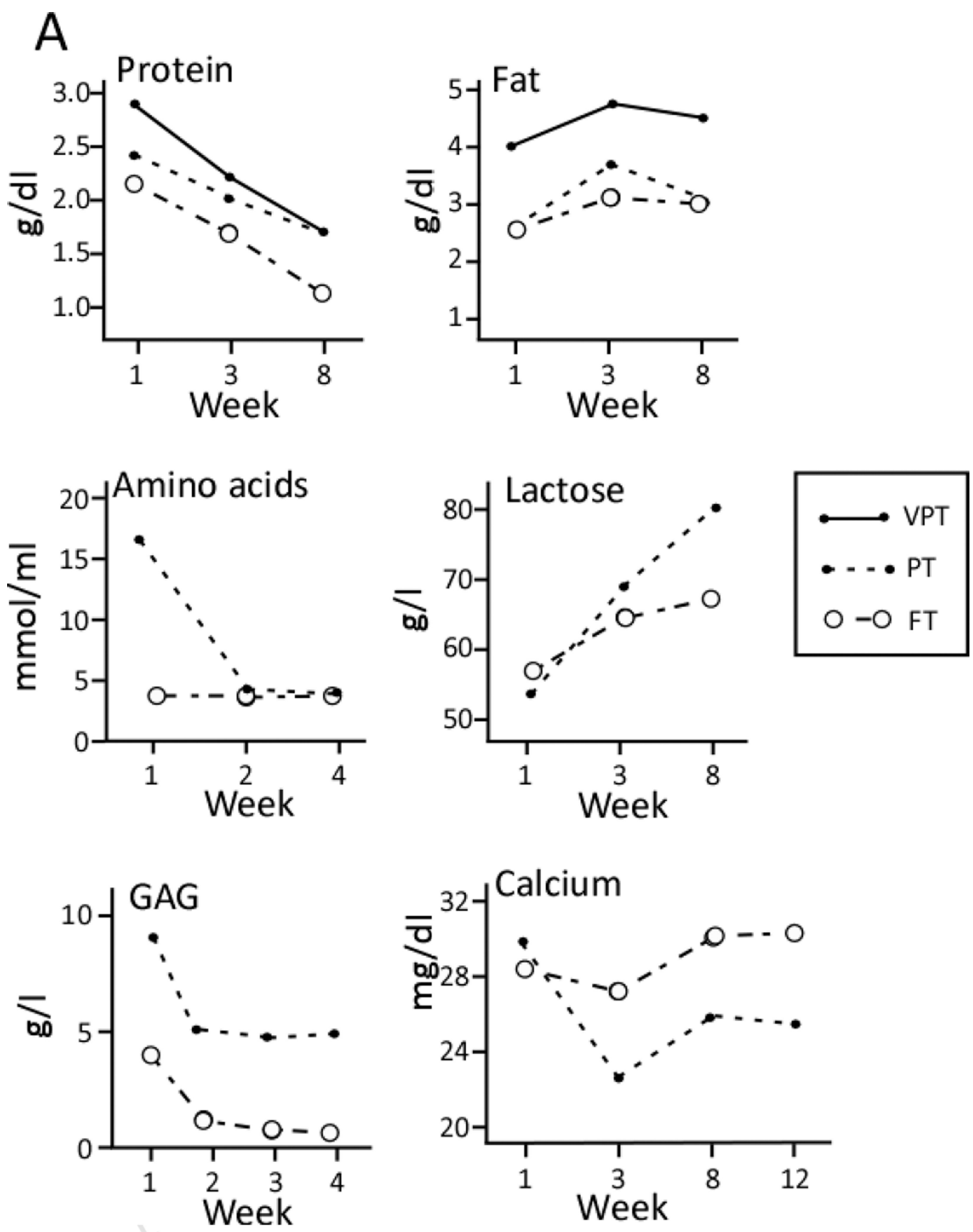

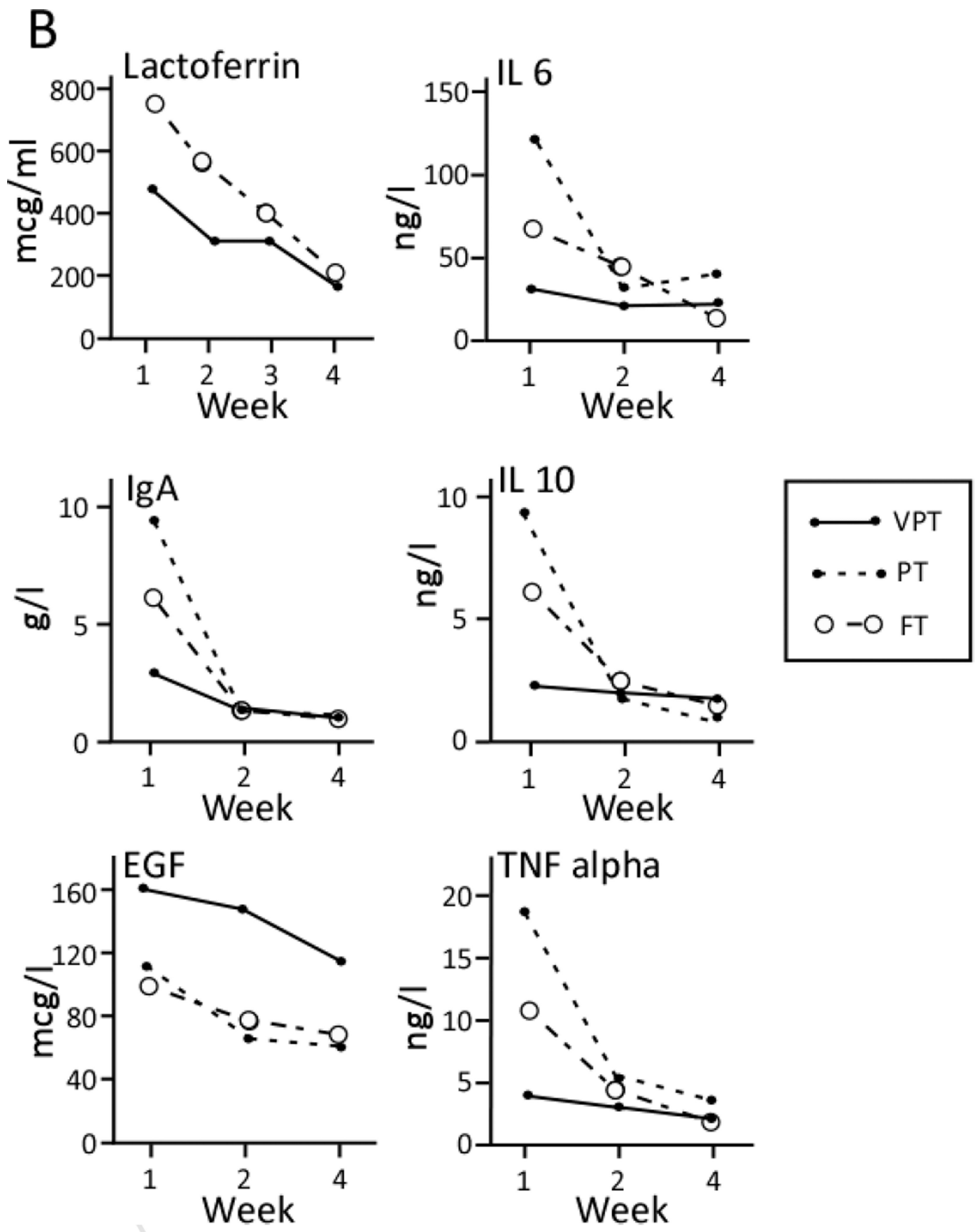

Figure 1.

Changes in milk composition over time in term (37-41 weeks), preterm (30-36 weeks) and very preterm $\left(<28-30\right.$ weeks) infants. Data combined from multiple sources. ${ }^{15}, 82,115-122$ GAG glycosaminoglycans, IL 6 interleukin 6, IgA immunoglobulin A, IL 10 interleukin 10, EGF epidermal growth factor, TNF alpha tumor necrosis factor alpha. 


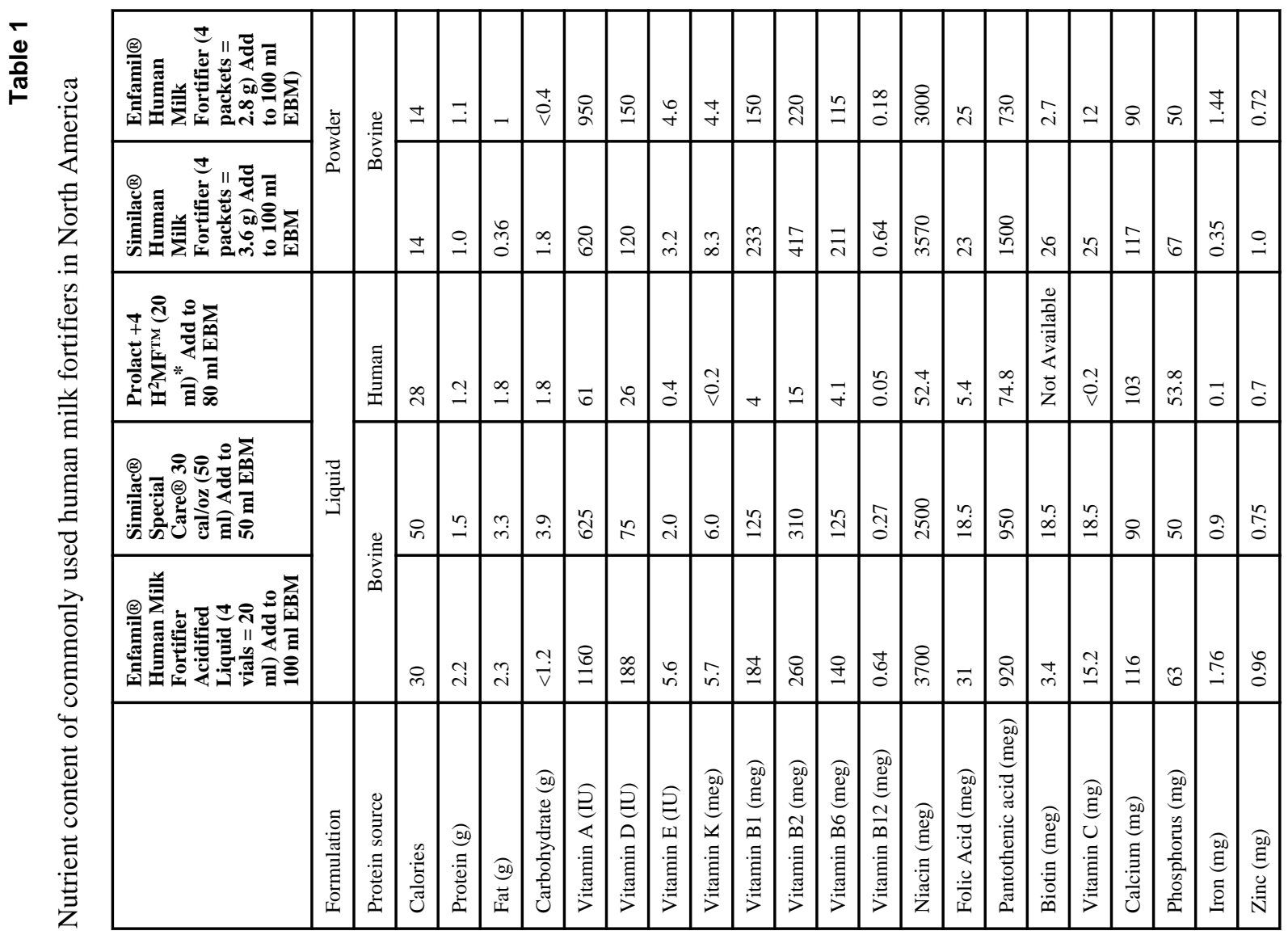

Pediatr Clin North Am. Author manuscript; available in PMC 2014 February 01. 


\begin{tabular}{|c|c|c|c|c|c|}
\hline \multicolumn{6}{|l|}{ Underwood } \\
\hline 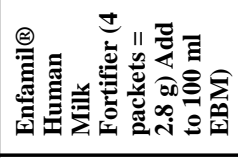 & $\exists$ & 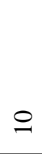 & $\stackrel{0}{2}$ & ते & $m$ \\
\hline 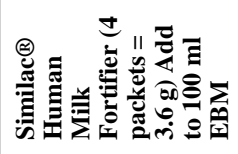 & 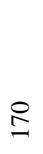 & $\stackrel{1}{\pi}$ & 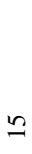 & 8 & $\infty$ \\
\hline 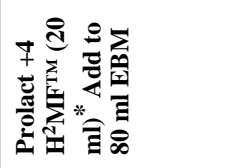 & t & $\frac{\mathcal{v}}{v}$ & $\hat{m}$ & in & iे \\
\hline 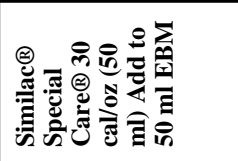 & $\cong$ & 6 & ส & 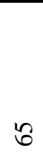 & $F$ \\
\hline 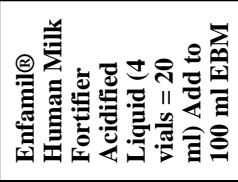 & 8 & 은 & $\hat{N}$ & if & $\stackrel{\sim}{\sim}$ \\
\hline & 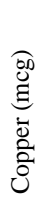 & 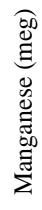 & 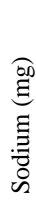 & 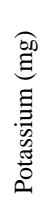 & 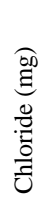 \\
\hline
\end{tabular}

